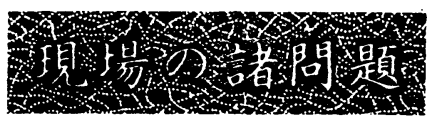

\section{LC-CD のタンパク質への応用*}

\section{1.はじめに}

タンパク質がタンパク質であるための高次構造，つま り構成アミノ酸がどのような空間配置をとっているかは X線解析により幾種かのタンパク質では明らかにされて いる. そしてこの方向はさらに進み，新しいタンパク質 の立体構造が数多く明らかにされていくものと思われ る. CDはX線解析のように立体構造の全体を細部に渡 って明らかにすることはできないが，分子の中に含まれ る種々の残基やグループの状態を調べてその構造や立体 環境を知る有力な手掛かりを提供してくれる.X線解析 されたタンパク質が增えてくれば，CDとの関係もより 明確になっていくと考えられる. そしてCDはX線解析 と比べれば，ずっと簡便に行えるので，タンパク質の種 々の機能を高次構造を通して理解するのに欠くことので きない方法である.ささらにX線との決定的な違いは，溶 液状態で測定するCDに対し，X線は固体状態で測定す ることである. タンパク質が生体内で，まるで海草やア メーバのように動的なものであることからして, 固体状 態の静的なものとしてのX線解析が果たして実際のタン パク質の挙動をどの程度まで推し量れるのか, 議論の余 地が残されている.

一方タンパク質の分離分析のための優れた HPLC 用の充塓剤が開発され，かなり実用化されてきた. その タンパク質を分離する時, 最も注意することとして, 活 性が落ちていないか，変化していないか，また，活性部 位はどこの画分に含まれているかなどが，問題になって くる.これらの状態を反映するのは，タンパク質の高次 構造にあるが，一般的に HPLC 用の検出器として使用 されているUVでは，その高次構造の情報を得ることは 難しい，そこで，タンパク質の光学活性検出器として, 従来の LC-CD ${ }^{1)}$ 飞改良を加えて, 微量 $(5-100 \mu \mathrm{g})$ なタ ンパク質, ペプチドにも適用が可能になったので紹介す る.

2. 従来の LC-CD の問題点と改良点 従来の HPLC 用の, たとえば，UV七ルをセルニニ

* Application of LC-CD for Proteins.
ットに取付，CDに装着する安易な方法で行うと，光の 利用率か低く，また，使用する溶出液によっては，その 吸収の影響が重大である。

そこで，以下のような改良を行い，目的物質が，微量 であったり，CD測定に障害を与えるような溶出夜を使 用した場合でも測定が可能になった。

フローセルを使用した時の C D 湘定には，次のことを 考虑する必要がある.

1 : 短波長ほど, 光源のエネルギーが急速に落ちること 2 ：使用する緩衝液自身による光吸収の影響があること そこで，LC-CD セルについて，以下の工夫を施した。 1 : 光エネルギー対策；CD装置の試料室に和ける光束 の口径は，8-10 mm $\phi$ であるために，フローセルの口径 を $2 \mathrm{~mm} \phi$ (ところで，あまり口径を大きくすると，石 英板の締め付けによる歪みが C D 湘定に影響を及ぼしや すくなるし，また，七ル容積をむ大きくするので，クロ マトグラフィーの立場から分離に影響をあたえる)とし， 更に集光器（石英レンズ）などを装着することにより光 束の全体を有効に利用できるようにした。

2 : 緩衝液の光吸收対策；たと之ば，一般的緩衝液の一 つであるトリスー塩酸系の場合 $220 \mathrm{~nm}$ 以下の吸収が, $\mathrm{CD}$ 測定を妨害する. そこで, フローセルの光路長を 1 $\mathrm{mm}$ もしく $2 \mathrm{~mm}$ とし, $220 \mathrm{~nm}$ 以下まで測定できる ようにした，ただし，中紫外一可視領域は，CDの感度 的に光路長が $10 \mathrm{~mm}$ のセルが必要であるので，この場合 に执いては，フローセルを通常のUVセル $(10 \mathrm{~mm})$ の ものに交換して, 測定できる.

セルの構造上で最む重要なポイントは, 光路方向と水 平方向に，石英を締め付け，押さえることである．垂直 に押さえるよらなセル構造にすると，歪みが生じ，CD 測定に決定的な打撃を与えてしまう。.

\section{3. 全体のシステムと測定方法}

CDR，2で述べたような改良を行った適当なフロー セル装置を装着し, これに, HPLCの溶出液を直接流し て，モニター（CDクロマトグラム）しながら，目的と する成分がセルの中に入った状態 HPLC での送液を止 め，CDスペクトルの測定を行った．全体のシステム構 成を図 1 に示した。

\section{4. 結果と考察}

まず基礎的な検討として，蒸留水及び $0.06 \%(\mathrm{w} / \mathrm{v})$ ammonium $d$-10-camphorsulfonate (ACS) を満たし た状態でCDスペクトルの測定を行った，その結果，前 者では，CDベースラインの蛇行は波長 700-185 nm 間 


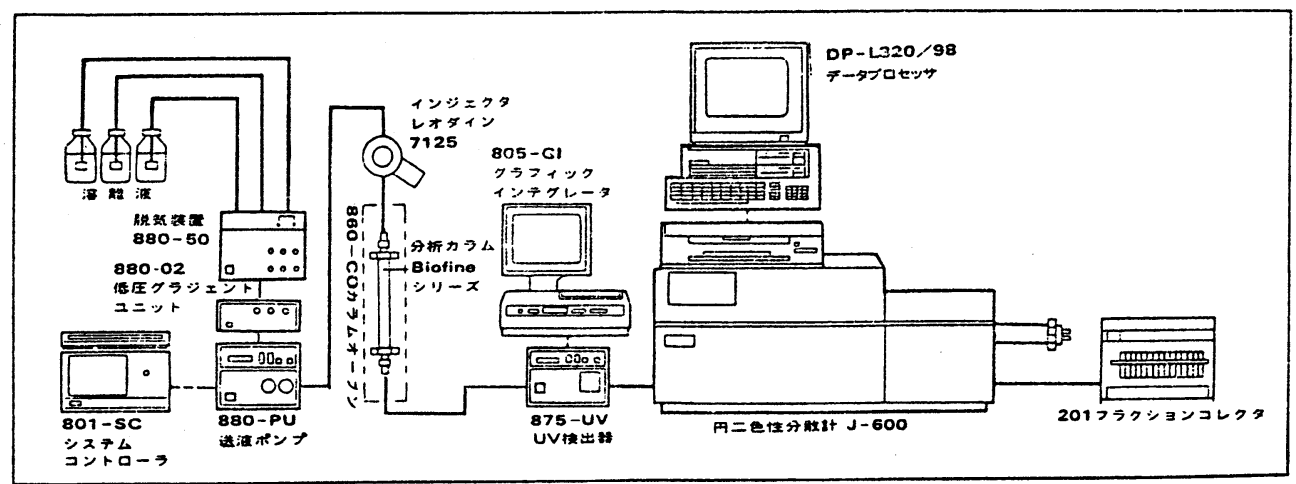

図 1 LC-CDシステム

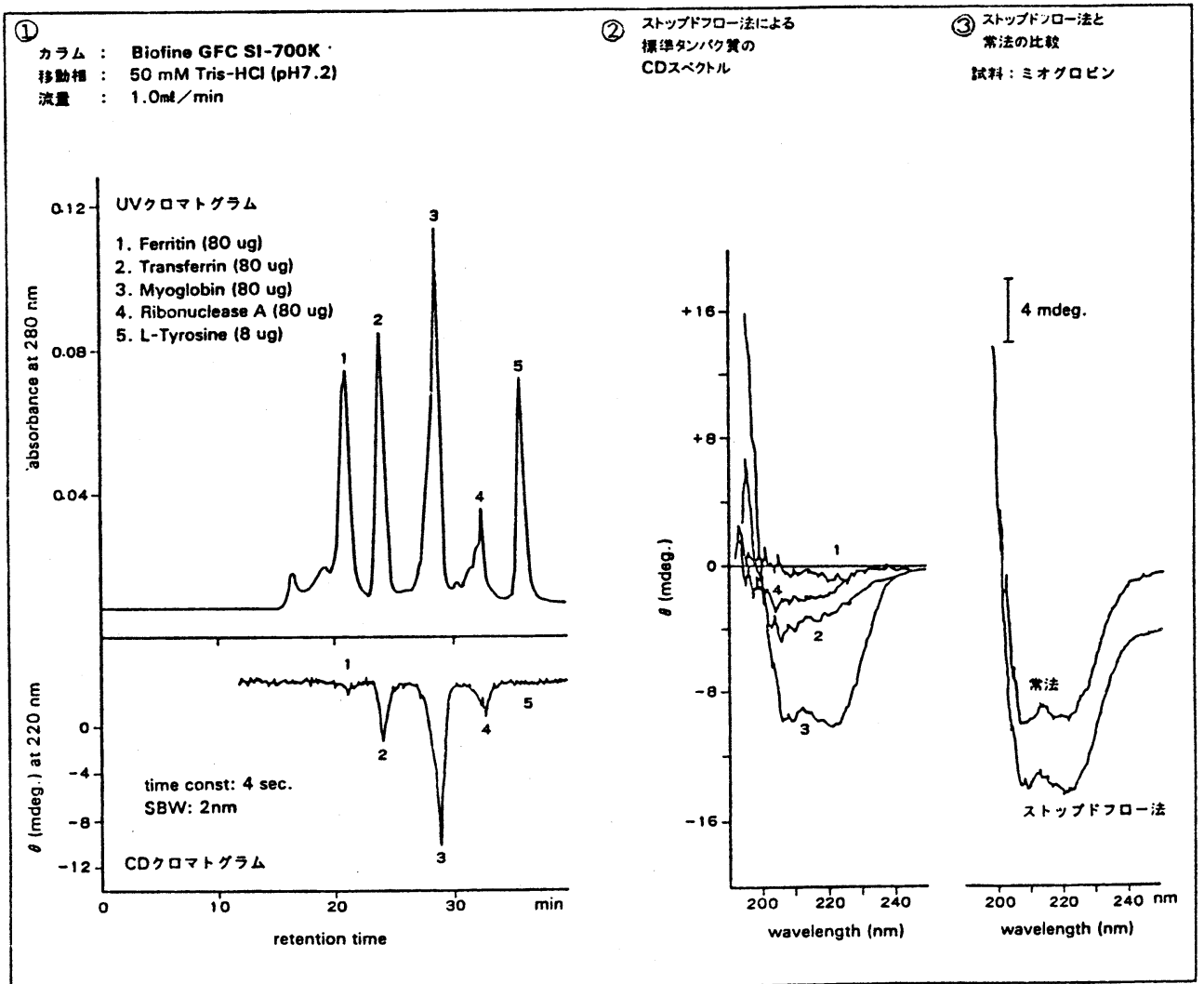

因 2 タンパク質混合物のゲルろ過クロマトグラフィー (GFC)

で, $10 \mathrm{mdeg}(\mathrm{SBW}=1 \mathrm{~nm})$ 以内であった. 後者では, CD-ratio, $[\theta]_{192}\left[[\theta]_{290.5}=-2.05 \pm(0.03)\right.$ (標準值はー2.03) であり，CD值の波長依存性に問題はなかっだ2。. また， グラジェント溶出法によるベースライン（CDクロマト グラム : 波長 $220 \mathrm{~nm}$ ) の安定性に㧊いても問題はなか
った.

上記の条件で，タンパク質及びペプチドの代表的な分 離モードであるゲル浸透クロマトグラフィー(GPC)，1 オン交換クロマトグラフィー(IEC) 及び逆相クロマトグ ラフィー(RPC)を行ったが, 都合よく測定できた. 代表 
例として，GFC の溶離図 ( CDクロマトグラム及びU V クロマトグラム) の一部を図 2-(1)に示した ${ }^{3-6)}$. CDク ロマトグラムでは, 感度の高い波長 $220 \mathrm{~nm}$ (さらによ り短波長でも可能）に拈いてモニターすることができた (最小検知感度 : $0.12 \mu \mathrm{g}$ ミオグロビン [time const = $4, \mathrm{~S} / \mathrm{N}=2])$. 又, ピーク頂点での各ピークのC D スペク トルを図 2-(2)を示したが, $195 \mathrm{~nm}$ 以下に扎いては，溶 媒の影響で測定は困難であった. 図2-(3)にミオグロビ ンを用いて，ストップドフロー法と対照（同一セルに $0.005 \%$ ミオグロビン溶液を満たしたもの）のCDスペ クトルを比較したが，同じようなパターンが得られてい る.

以上の結果より,タンパク質の二次構造解析も可能な 検出器として，タンパク質及びペプチドの活性または， その活性部位に着目したタンパク質, ペプチドの HPLC に大きく貢献するものと期待される.

\section{文献}

1）和田明生, 高桑 堯, 金内芙美子, 坂柳信之：分析 化学討論会, p. 7 (1986).

2) T. Takakuwa, T. Kondo, H. Meguro: Analytical Siences, 1, 215-218 (1985).

3) T. Takakuwa, Y. Kurosu, et al: J. Liq. Chromatog. (in press).

4) 黒須泰行, 高桑 堯ら：第 7 回液体 クロマトグラフ 1一討論会, p. 101 (1986).

5）黑須泰行, 高桑 堯, 坂柳信之, 千田正昭 : 第 60 回 生化学, p. 739 (1987).

6) OE. カスティリオー二, 高桑 蕘, 黒須泰行ら: 第 2 回 C D国際会議 (1987).

（日本分光 黒須泰行*，高桑 堯）

\footnotetext{
* Yasuyuki Kurosu and Takashi TaKakUwa, Japan Spectroscopic Co., Ltd (JASCO).
} 